\title{
Sites of Infection by Pythium Species in Rice Seedlings and Effects of Plant Age and Water Depth on Disease Development
}

\author{
S.-C. Chun and R. W. Schneider
}

Department of Plant Pathology and Crop Physiology, Louisiana Agricultural Experiment Station, Louisiana State University Agricultural Center, Baton Rouge 70803.

Accepted for publication 17 August 1998.

\begin{abstract}
Chun, S.-C., and Schneider, R. W. 1998. Sites of infection by Pythium species in rice seedlings and effects of plant age and water depth on disease development. Phytopathology 88:1255-1261.

Seedling disease, caused primarily by several species of Pythium, is one of the major constraints to water-seeded rice production in Louisiana. The disease, also known as water-mold disease, seed rot, and seedling damping-off, causes stand reductions and growth abnormalities. In severe cases, fields must be replanted, which may result in delayed harvests and reduced yields. To develop more effective disease management tactics including biological control, this study was conducted primarily to determine sites of infection in seeds and seedlings; effect of plant age on susceptibility to $P$. arrhenomanes, $P$. myriotylum, and $P$. dissotocum; and minimum exposure times required for infection and seedling death. In addition, the effect of water depth on seedling disease was investigated. Infection rates of seed embryos were significantly higher than those of endosperms

for all three Pythium spp. The development of roots from dry-seeded seedlings was significantly reduced by $P$. arrhenomanes and $P$. myriotylum at 5 days after planting compared with that of roots from noninoculated controls. Susceptibility of rice to all three species was sharply reduced within 2 to 6 days after planting, and seedlings were completely resistant at 8 days after planting. There was a steep reduction in emergence through the flood water, relative to the noninoculated control, following 2 to 3 days of exposure to inoculum of $P$. arrhenomanes and P. myriotylum. In contrast, $P$. dissotocum was much less virulent and required longer exposure times to cause irreversible seedling damage. Disease incidence was higher when seeds were planted into deeper water, implying that seedlings become resistant after they emerge through the flood water. These results suggest that disease control tactics including flood water management need to be employed for a very short period of time after planting. Also, given that the embryo is the primary site of infection and it is susceptible for only a few days, the disease should be amenable to biological control.
\end{abstract}

Seedling diseases that cause stand reductions and growth abnormalities can affect rice (Oryza sativa L.) in water-seeded fields, seedbeds grown for transplanting, and seed boxes used in mechanical transplanting operations (20). Damping-off in rice was first described by Sawada in 1912 in Taiwan (21) and then in Japan (12), Korea (25), Bangladesh (22), and India (23). This disease is not an economic problem in rice in the tropics (16). In the United States, seedling disease was reported in water-seeded rice in California (20) and Louisiana $(13,14,18,20)$. One of the important seedling diseases in Louisiana is damping-off, also known as seed rot and water-mold disease (20). In severe cases, fields must be replanted, which may result in delayed harvests and reduced yields (9).

The disease is caused by Achlya spp., Pythium spp., and at least one Fusarium sp. (20). When seeds are attacked immediately after sowing, they do not germinate or fail to emerge through the flood water because endosperms or embryos may be infected by species of Achlya or Pythium, respectively $(13,20)$. If the weather is favorable for plant growth, surviving seedlings often recover and may not be severely damaged (20). The disease usually develops when seedlings lack vigor and is often exacerbated by cool, cloudy weather that retards germination and seedling growth (16).

In Louisiana, seedling disease is most severe when seeds are sown from airplanes directly into flooded fields (water seeding) (9). This method of planting, as opposed to drill seeding, circumvents problems associated with conventional planting into fields that may be continually wet by early season rains. Furthermore, fields can be prepared during the previous fall and maintained in a rain-fed flood-

Corresponding author: R. W. Schneider; E-mail address: rschnei@unix1.sncc.lsu.edu

Publication no. P-1998-0928-01R

(C) 1998 The American Phytopathological Society ed state throughout the winter and early spring. Weed control is another major benefit of maintaining a prolonged continuous flood followed by water seeding $(1,9)$. In addition, nitrogen-use efficiency is greatly enhanced if fields can be maintained in a continuous flooded state after planting (1). Thus, seedling disease is costly not only because of its direct effect on stand establishment when seeds are planted into flooded fields but also because of altered water and fertilizer nitrogen management practices that must be implemented. Cultural control practices consist of precision land leveling to maintain a uniform shallow flood combined with draining and reflooding shortly after planting. The latter practice stimulates root growth and penetration into soil (1). With regard to shallow floods, field observations suggested that seedlings become resistant after shoots emerge from the water, though no report was found in which this question was addressed with controlled experiments. The use of pregerminated seeds, as opposed to dry seeds, is another practice that, until recently, was widely used. This practice involves loading seeds into large porous bags, briefly immersing the bags in a large tank of water, allowing the seeds to drain, and then planting the wet pregerminated seeds from airplanes within 1 or 2 days. Sowing pregerminated seeds results in faster emergence through the flood water and less seedling disease (D. E. Groth, personal communication). However, this practice is being discontinued because of environmental problems associated with disposing of the water from the dunk tanks (D. E. Groth, personal communication).

The objectives of this research were to determine (i) the sites of infection in rice seedlings by Pythium spp. in pregerminated and dry-planted seeds; (ii) the minimum exposure time required for pathological effects; (iii) the effect of plant age on susceptibility to Pythium spp; and (iv) the effect of water depth on disease incidence. It was felt that this information would be useful in devising or improving cultural, chemical, and biological control measures. Preliminary reports were published $(3,4)$. 


\section{MATERIALS AND METHODS}

The pathosystem. Rice seeds ( $20 \mathrm{~g}$, cv. Lemont) were soaked for $2 \mathrm{~h}$ in a freshly prepared solution of 50\% household bleach (2.6\% NaOCl; Clorox; Clorox Co., Oakland, CA) adjusted to $\mathrm{pH} 7.3$ with $0.6 \mathrm{M} \mathrm{KH}_{2} \mathrm{PO}_{4}(1: 1, \mathrm{vol} / \mathrm{vol})$ (5). Seeds then were rinsed four times in $300 \mathrm{ml}$ of sterile distilled water. Dry-planted seeds were sown immediately, while pregerminated seeds were incubated in sterile buffered water ( $\mathrm{pH} 7.1,1.0 \mathrm{mM}$ potassium phosphate) in culture tubes for $4 \mathrm{~h}$, drained, and then incubated in the culture tubes for an additional 2 days at room temperature before being planted. Unless indicated otherwise, dry-planted seeds were used for all experiments.

Soil (sand/loam soil, 1:1) was autoclaved for $30 \mathrm{~min}$ on each of 2 consecutive days, and $50 \mathrm{~cm}^{3}$ of soil was added to each sterilized glass storage dish ( 80 by $100 \mathrm{~mm}$ ) containing $100 \mathrm{ml}$ of sterile buffered water. Inoculum was prepared by transferring three mycelial plugs of each of the Pythium spp. from corn meal agar (CMA) plates into each 250-ml Erlenmeyer flask containing $100 \mathrm{ml}$ of potato dextrose broth and incubating on a rotary shaker $(100 \mathrm{rpm})$ at room temperature for 7 to 10 days. Mycelial masses were collected on a $0.5-\mathrm{mm}$-mesh sieve and washed five times with sterile distilled water. The mycelia were then triturated in sterile buffered water for $10 \mathrm{~s}$ in a blender at low speed. The optical density $(600 \mathrm{~nm})$ of the mycelial suspensions was adjusted to 1.5 with a spectrophotometer. Ten disinfested rice seeds were planted in each glass storage dish, and $1.5 \mathrm{ml}$ of mycelial inoculum of $P$. arrhenomanes (strain 1398), P. myriotylum (strain 1397), or P. dissotocum (strain 1374) was added to each dish. The same strains of each species were used throughout this study; they were selected because they were the most virulent of all strains tested within the respective species (R. W. Schneider, unpublished data). The dishes were placed in a growth chamber set at $30 / 20^{\circ} \mathrm{C}$ (day/night) with $12 \mathrm{~h}$ of light per day. The light source was four 40-watt, cool-white fluorescent bulbs.

Experiments were conducted several times, with four or five replications per treatment, although plants were not necessarily sampled at the same time in each experiment. Therefore, results could not be combined across experiments because some sampling times would have more replications than others. Also, there were small differences among experiments in emergence and dry weight in the experimental controls; although all trends were confirmed in each repetition. For these reasons, only the results from the last experiment, which included all sampling times, are presented. Data were subjected to analysis of variance, and means were separated with
Student-Newman-Keuls', Fisher's protected least significant difference, and Dunnett's tests (Minitab version 11; Minitab, Inc., State College, PA; 24).

Dissection of rice seeds and seedlings and recovery of Pythium spp. Seeds and seedlings were collected from the storage dishes at 1,3 , and 5 days after planting, rinsed with sterile distilled water, dipped in 70\% alcohol, blotted on paper towels, and dissected with the aid of a stereo microscope into embryos (before shoot elongation) or scutellar remains of the embryos (after removing and plating elongated shoots and roots, if present) (Fig. 1A and B) and endosperms (8). Scutellar remains were composed primarily of epiblasts and scutella. The dissected parts were plated on a Pythium-selective medium (PV) (15) that was modified by the addition of spectinomycin $(300 \mu \mathrm{g} / \mathrm{ml}$; J. W. Hoy, personal communication). Plates were incubated at $28^{\circ} \mathrm{C}$ with $12 \mathrm{~h} /$ day fluorescent light and monitored daily for 5 days. Also, the number of seedlings with roots was recorded at 5 days after planting to determine if Pythium spp. inhibited root development.

Use of metalaxyl in etiological studies. Metalaxyl (Ridomil 2E [25.1\% $N$-(2,6-dimethyl-phenyl)- $N$-(methoxyacetyl) alanine methyl ester]; Novartis Corp., Greensboro, NC), a fungicide with activity against Pythium spp., was used to inhibit infection in certain etiological studies. However, before those studies could be conducted, it was necessary to determine the fungicide concentrations that inhibited Pythium but caused minimal phytotoxic responses in rice seedlings under growth chamber conditions. Mycelial blocks ( 2 by $2 \mathrm{~mm}$ ) of $P$. arrhenomanes from a CMA plate were transferred to CMA plates amended with metalaxyl at $0,5,10,25$, and $50 \mu \mathrm{l}$ of active ingredient per liter. All concentrations are expressed as active ingredient. The plates were incubated at $28^{\circ} \mathrm{C}$ in darkness, and radial growth was determined by measuring colony diameters on two perpendicular axes in each plate every day for 5 days. A total of 25 rice seeds was planted in each storage dish containing $50 \mathrm{~cm}^{3}$ of autoclaved soil and $100 \mathrm{ml}$ of sterile buffered water, prepared as described above, but the water was amended with metalaxyl at $0,5,10,25$, and $50 \mu \mathrm{l} /$ liter. Seedling emergence through the water and shoot and root dry weights were determined at 10 days after planting.

Minimum exposure time required for pathological effects and effect of plant age on susceptibility to Pythium spp. After seeds were planted in storage dishes containing infested soil and water as described above, the water was amended with metalaxyl at the rate of $10 \mu \mathrm{l} /$ liter at daily intervals up to 10 days after planting. Seedling emergence through the water was determined 10 days
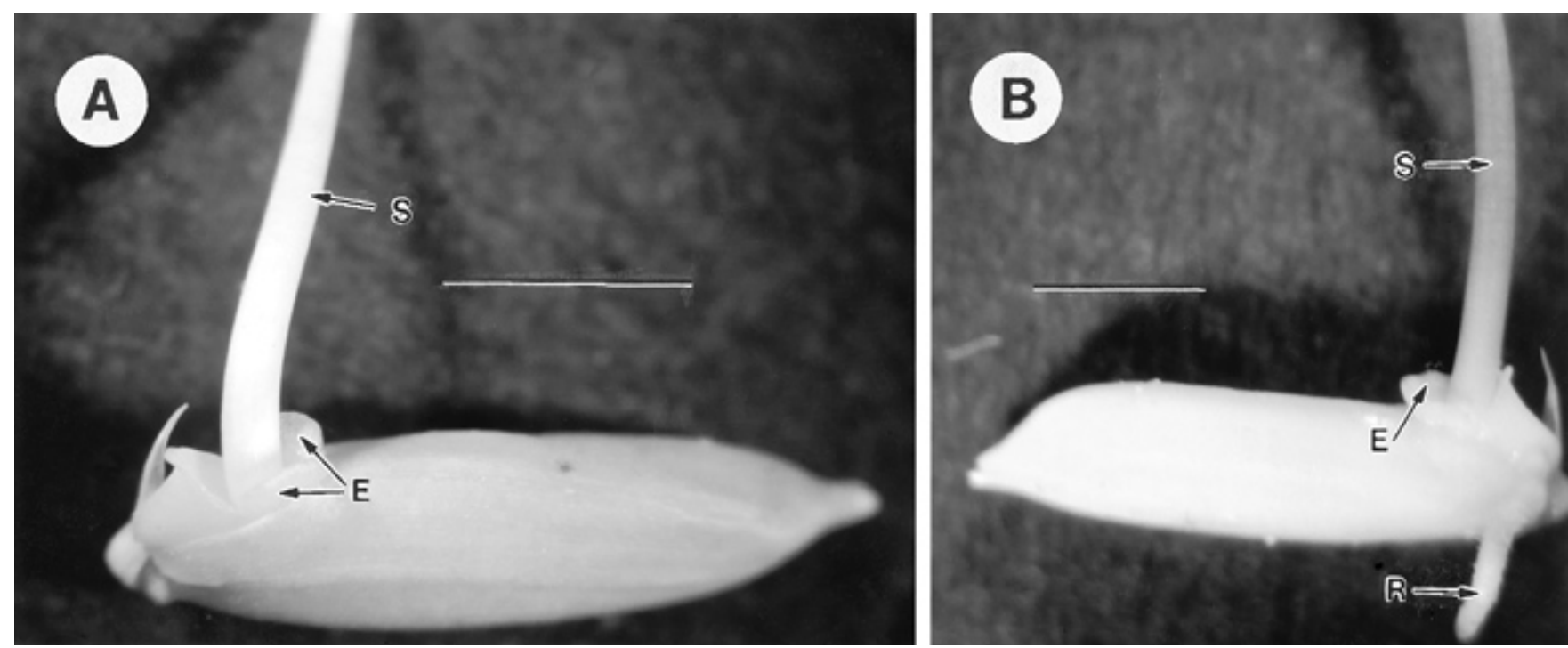

Fig. 1. Noninoculated rice seedlings grown under flooded conditions in a growth chamber set at $30 / 20^{\circ} \mathrm{C}$ (day/night) with $12 \mathrm{~h} /$ day of light for $\mathbf{A}, 4$ and $\mathbf{B}, 5$ days. A newly emerged root is visible in $\mathbf{B}$. $\mathrm{S}=$ shoot, $\mathrm{E}=$ epiblast, and $\mathrm{R}=$ root. Bars $=3.0 \mathrm{~mm}$. 
after application of metalaxyl. Experimental treatments were considered to be the number of days after planting at which metalaxyl was added. For determining the effect of plant age on susceptibility, Pythium spp. were inoculated into storage dishes as described above at daily intervals from 0 to 8 days after seeds were planted. Seedling emergence through the water and total plant dry weight were determined 10 days after inoculation.

Effect of water depth on susceptibility to Pythium spp. Storage dishes were prepared and incubated as described above, except that two volumes of sterile water were used. Water depths of 1.5 and $4.5 \mathrm{~cm}$ were achieved by adding 100 and $300 \mathrm{ml}$ of sterile water, respectively. The storage dishes were inoculated as described above with $P$. arrhenomanes at 0,2 , and 4 days after planting and with $P$. dissotocum at 0 days only. The amount of inoculum added to each storage dish, $1.5 \mathrm{ml}$, was the same for both water depths, because the triturated mycelium settled to the soil surface within a few hours. If the inoculum had remained suspended in the water, inoculum density would have been expressed as propagules per $\mathrm{cm}^{3}$ of water. However, with the inoculum settling, propagules per $\mathrm{cm}^{2}$ of soil surface would not be affected by water depth.
Seedling emergence through the water was determined at 14 days after planting.

\section{RESULTS}

Infection sites of Pythium spp. in germinating rice seeds. In dry-seeded rice, shoots and embryos or scutella were the primary sites of infection within 3 days of planting into infested water (Figs. 1 and 2). Except for infection by $P$. myriotylum, endosperms and roots, when they were present, had the lowest rates of infection over time (Fig. 2). Seeds and seedlings from pregerminated seeds had higher rates of infection over time compared with dry seeds, and shoots and embryos or scutella were the primary sites of infection (Fig. 2). With P. dissotocum, shoots and embryos or scutella from pregerminated seeds were highly infected within 1 day of planting (Fig. 2). Also, P. arrhenomanes was particularly noteworthy in its ability to infect shoots, roots, and embryos or scutella, but not endosperms, within 3 days of planting (Fig. 2). There was no discoloration or necrosis on any of the seeds or seedling parts in these studies (Fig. 3). However, shoot and root growth were retarded, and there
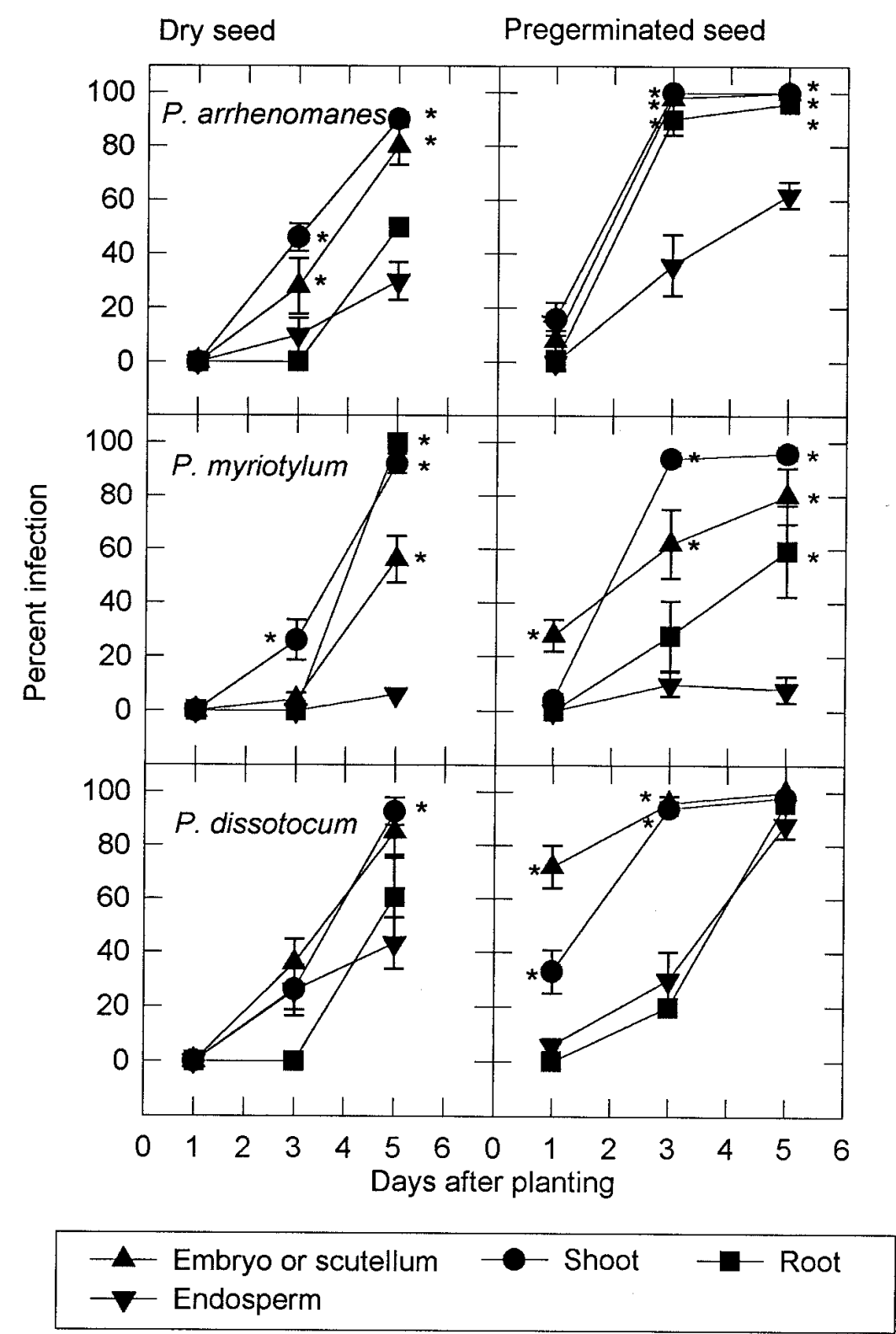

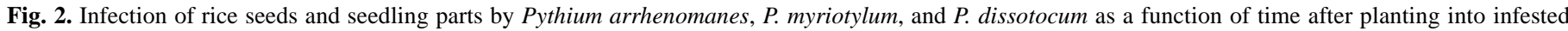
water. Bars indicate standard error of the mean; * indicates that infection rates were significantly higher than those of endosperms $($ Dunnett's, $P=0.05)$. 
were morphological abnormalities such as twisted and bent shoots in infected seedlings (Fig. 3).

Dry-seeding as compared with sowing pregerminated seeds resulted in complete inhibition of root development and growth for all three Pythium spp. at 5 days after planting (Table 1, Fig. 3). $P$. dissotocum had no effect on root growth when pregerminated seeds were used (Table 1).

Use of metalaxyl in etiological studies. Radial growth of $P$. arrhenomanes was reduced by $90 \%$ relative to the control at $4 \mu \mathrm{l}$ of metalaxyl per liter. Metalaxyl at up to $25 \mu \mathrm{l} /$ liter did not affect seedling emergence through the water or shoot length, root length, or root dry weight relative to the control (Table 2). However, shoot dry weight was sensitive at levels below $25 \mu \mathrm{l} /$ liter (Table 2).

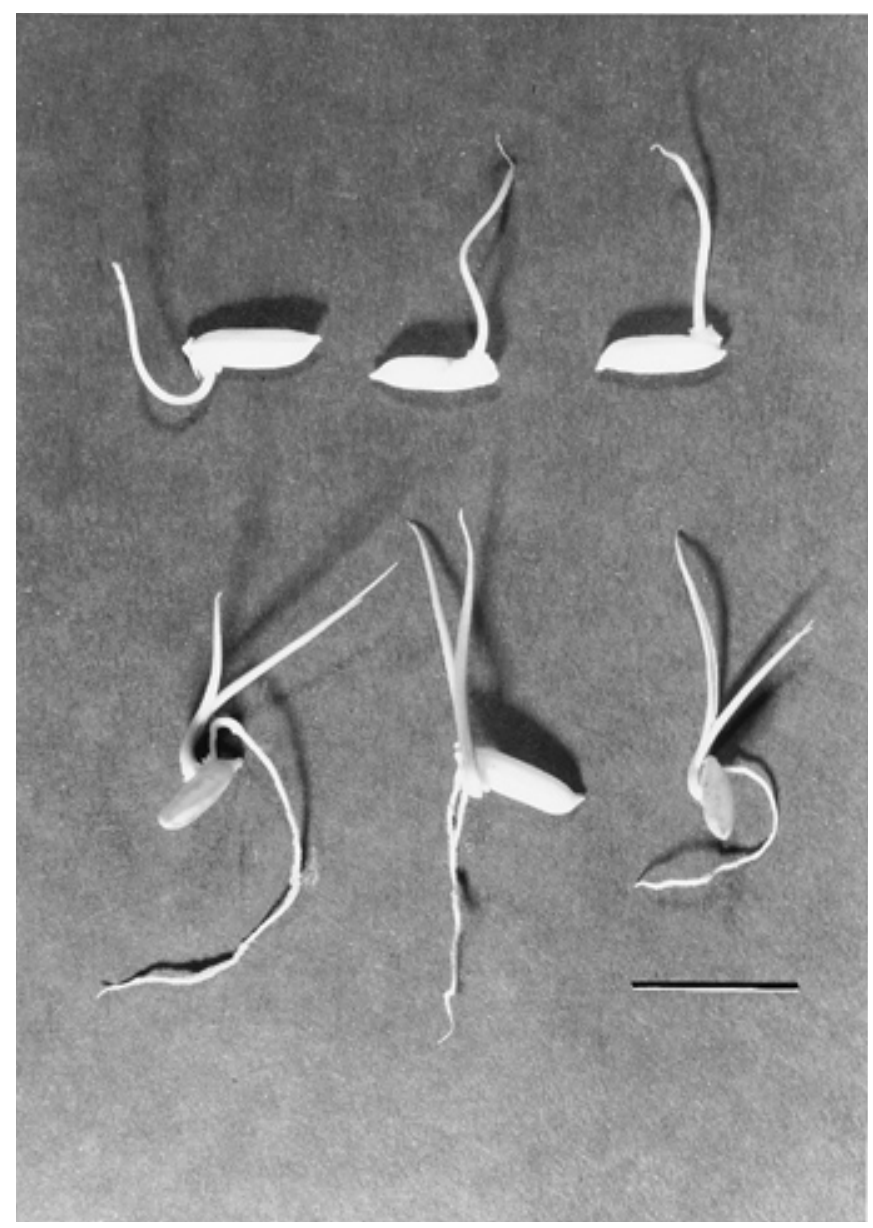

Fig. 3. Rice seedlings grown under flooded conditions in a growth chamber set at $30 / 20^{\circ} \mathrm{C}$ (day/night) with $12 \mathrm{~h} /$ day of light for 8 days and either (top row) inoculated with Pythium arrhenomanes or (bottom row) noninoculated. Text contains inoculation procedure details. Note the absence of roots in the inoculated seedlings. Bar $=1.0 \mathrm{~cm}$.

TABLE 1. Effects of planting method and Pythium spp. on root development at 5 days after planting into infested water

\begin{tabular}{lccccc}
\hline & \multicolumn{4}{c}{ Percent $^{\mathrm{w}}$ seedlings with roots } \\
\cline { 2 - 5 } Planting & $\begin{array}{c}\text { Noninoculated } \\
\text { control }\end{array}$ & $\begin{array}{c}\text { P. } \\
\text { method }\end{array}$ & $\begin{array}{c}\text { arrenomanes } \\
\text { myriotylum }\end{array}$ & $\begin{array}{c}\text { dissotocum } \\
\text { LSD }\end{array}$ & mSD $^{\mathrm{x}}$ \\
\hline Dry-seeded & $90 \mathrm{a}^{\mathrm{y}}$ & $4 \mathrm{~b}$ & $10 \mathrm{~b}$ & $24 \mathrm{~b}$ & 18.7 \\
Pregerminated $^{\mathrm{z}}$ & $94 \mathrm{a}$ & $52 \mathrm{a}$ & $46 \mathrm{a}$ & $100 \mathrm{a}$ & 22.0 \\
\hline
\end{tabular}

${ }^{w}$ Statistical analysis was conducted following arcsine transformation of percent seedling emergence through the water.

${ }^{x}$ Least significant difference $(P=0.05)$ for mean comparisons within rows.

y Means followed by same letters within columns are not significantly different (Student-Newman-Keuls', $P=0.05$ ).

z Seeds were soaked in distilled water for $3 \mathrm{~h}$, and then drained and incubated at room temperature for 2 days before planting.
Minimum exposure time required for pathological effects and effect of plant age on susceptibility to Pythium spp. Seedling emergence through the water, relative to the noninoculated control, was sharply reduced by $P$. arrhenomanes and $P$. myriotylum following 2 to 3 days of exposure to inoculum (metalaxyl applied

TABLE 2. Effect of different concentrations of metalaxyl on emergence and seedling growth in ricew

\begin{tabular}{lllllll}
\hline & & \multicolumn{2}{c}{ Shoot } & & \multicolumn{2}{c}{ Root } \\
\cline { 7 - 8 } Concentration $^{\mathrm{x}}$ & $\begin{array}{c}\text { Emergence } \\
(\%)^{\mathrm{y}}\end{array}$ & $\begin{array}{c}\text { Length } \\
(\mathrm{cm})\end{array}$ & $\begin{array}{c}\text { Dry weight } \\
(\mathrm{mg})\end{array}$ & & $\begin{array}{c}\text { Length } \\
(\mathrm{cm})\end{array}$ & $\begin{array}{c}\text { Dry weight } \\
(\mathrm{mg})\end{array}$ \\
\hline 0 & $91 \mathrm{a}^{\mathrm{z}}$ & $6.2 \mathrm{a}$ & $3.0 \mathrm{a}$ & & $5.3 \mathrm{a}$ & $2.4 \mathrm{a}$ \\
5 & $92 \mathrm{a}$ & $5.3 \mathrm{ab}$ & $2.3 \mathrm{~b}$ & & $4.7 \mathrm{a}$ & $1.7 \mathrm{a}$ \\
10 & $89 \mathrm{a}$ & $5.8 \mathrm{ab}$ & $2.8 \mathrm{a}$ & & $5.1 \mathrm{a}$ & $2.3 \mathrm{a}$ \\
20 & $87 \mathrm{a}$ & $5.6 \mathrm{ab}$ & $2.3 \mathrm{~b}$ & & $5.0 \mathrm{a}$ & $2.0 \mathrm{a}$ \\
25 & $90 \mathrm{a}$ & $5.8 \mathrm{ab}$ & $2.6 \mathrm{~b}$ & & $5.5 \mathrm{a}$ & $2.1 \mathrm{a}$ \\
50 & $91 \mathrm{a}$ & $4.5 \mathrm{~b}$ & $1.9 \mathrm{c}$ & & $5.1 \mathrm{a}$ & $1.6 \mathrm{a}$ \\
\hline
\end{tabular}

${ }^{w}$ Seeds were planted in storage dishes containing $50 \mathrm{~cm}^{3}$ of steam-sterilized soil and $100 \mathrm{ml}$ of sterile buffered water amended with metalaxyl. Measurements were taken at 10 days after planting.

${ }^{x}$ Metalaxyl concentration, $\mu \mathrm{l}$ of active ingredient per liter.

y Statistical analysis was conducted following arcsine transformation of percent seedling emergence through the water.

${ }^{\mathrm{z}}$ Means followed by same letters within columns are not significantly different (Student-Newman-Keuls', $P=0.05$ ).

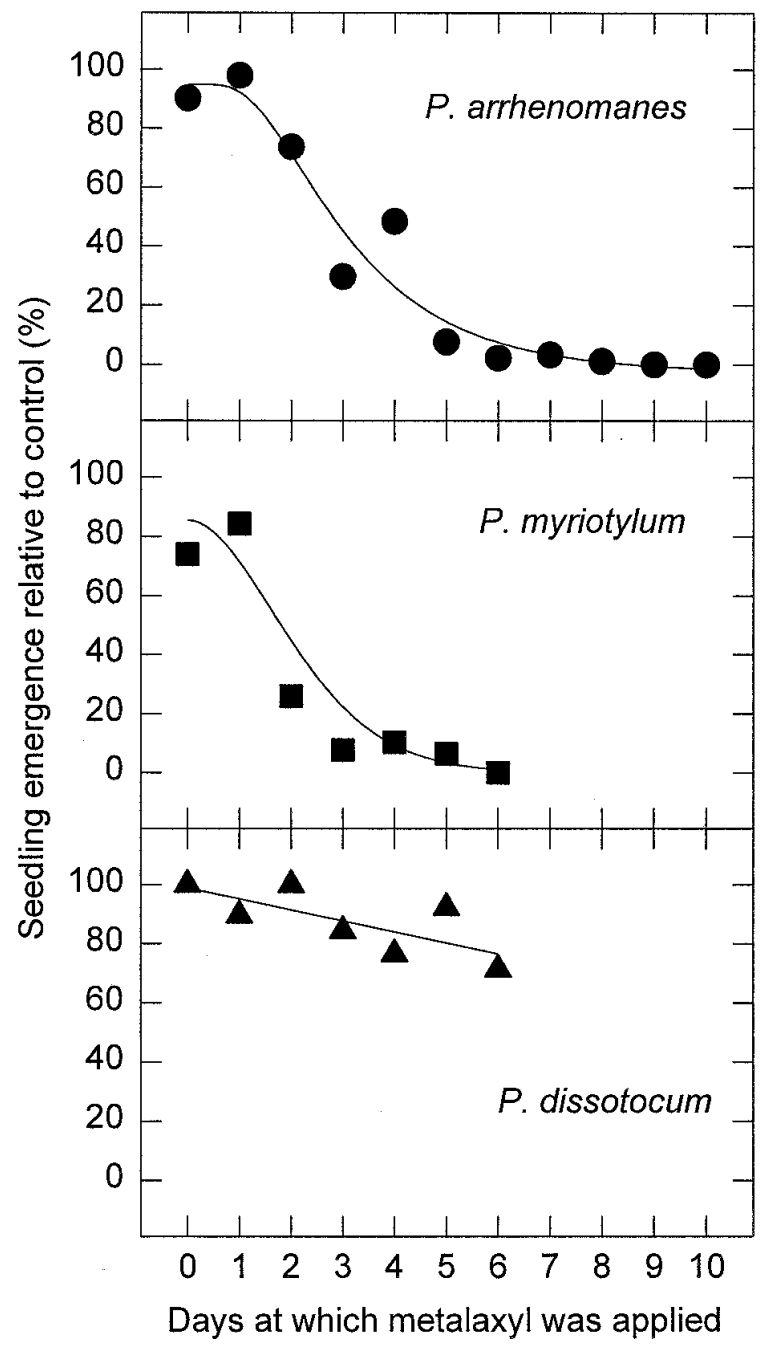

Fig. 4. Rice seedling emergence as a function of time after planting at which three Pythium spp. were controlled by the addition of metalaxyl to the flood water. Seedling emergence in the noninoculated controls ranged from 72 to $88 \%$. Lines were added for illustrative purposes. 
after 2 to 3 days) (Fig. 4). However, inoculation with $P$. dissotocum resulted in a gradual reduction in seedling emergence through the water over the 6-day period of exposure (Fig. 4). For $P$. dissotocum, there was an inverse linear relationship $(r=-0.73, P=0.063)$ between days of exposure to inoculum and seedling emergence, relative to the noninoculated control.

Susceptibility of rice to Pythium spp. was sharply reduced within 2 to 6 days of planting (Fig. 5). For P. dissotocum and P. myriotylum, there was an abrupt increase in resistance (as measured by emergence) at 2 and 4 days after planting, respectively, while for $P$. arrhenomanes, there was a more gradual increase in disease resistance up to 8 days after planting (Fig. 5). Plant growth, as measured by shoot and root dry weights, showed trends that were similar to changes in resistance (Fig. 5). It should be noted that all plants were assessed for dry weight at the same time after planting.

Effect of water depth on susceptibility to Pythium spp. Seedling emergence through the water was significantly reduced by the higher water level when water in the storage dishes was infested with Pythium spp. at 2 and 4 days after planting for $P$. arrhenomanes and at the time of planting for $P$. dissotocum. In the case of $P$. arrhenomanes, there was no seedling emergence through the water when the water was infested at the time of planting, regardless of depth (Fig. 6). Results from previous experiments (data not shown) showed that $P$. dissotocum did not affect seedling emergence through the water, regardless of water depth, when inoculum was added at 2 or more days after planting. In noninoculated, dry-seeded controls, approximately 6 and 8 days were required for $50 \%$ emergence in the low and high water depths, respectively, and use of pregerminated seeds reduced these intervals by about 2 days.

\section{DISCUSSION}

Our results indicate that, under conditions favorable for disease development, Pythium spp. infected rice embryos during the seed germination process within 2 to 3 days after planting and that this infection prevented emergence through the flood water. However, the period of susceptibility was very short, in that germinating seeds and seedlings became highly resistant to infection within 3 to 4 days after planting. Furthermore, once begun, the infection process must proceed uninterrupted for at least 3 days in order to affect seedling emergence. These relationships may vary under different temperature regimes, although we would not expect higher disease incidences because these experiments were conducted under environmental conditions that were most conducive to disease development (26). In addition, the development of roots from dryseeded rice was significantly reduced by Pythium spp. It should be noted that there was no tissue discoloration associated with these pathological effects, although shoots were occasionally twisted as a result of infection.

These effects alone may account for reduced emergence in the field, where it is commonly observed that shoot growth is retarded and root development is greatly impaired while seedlings are sub-

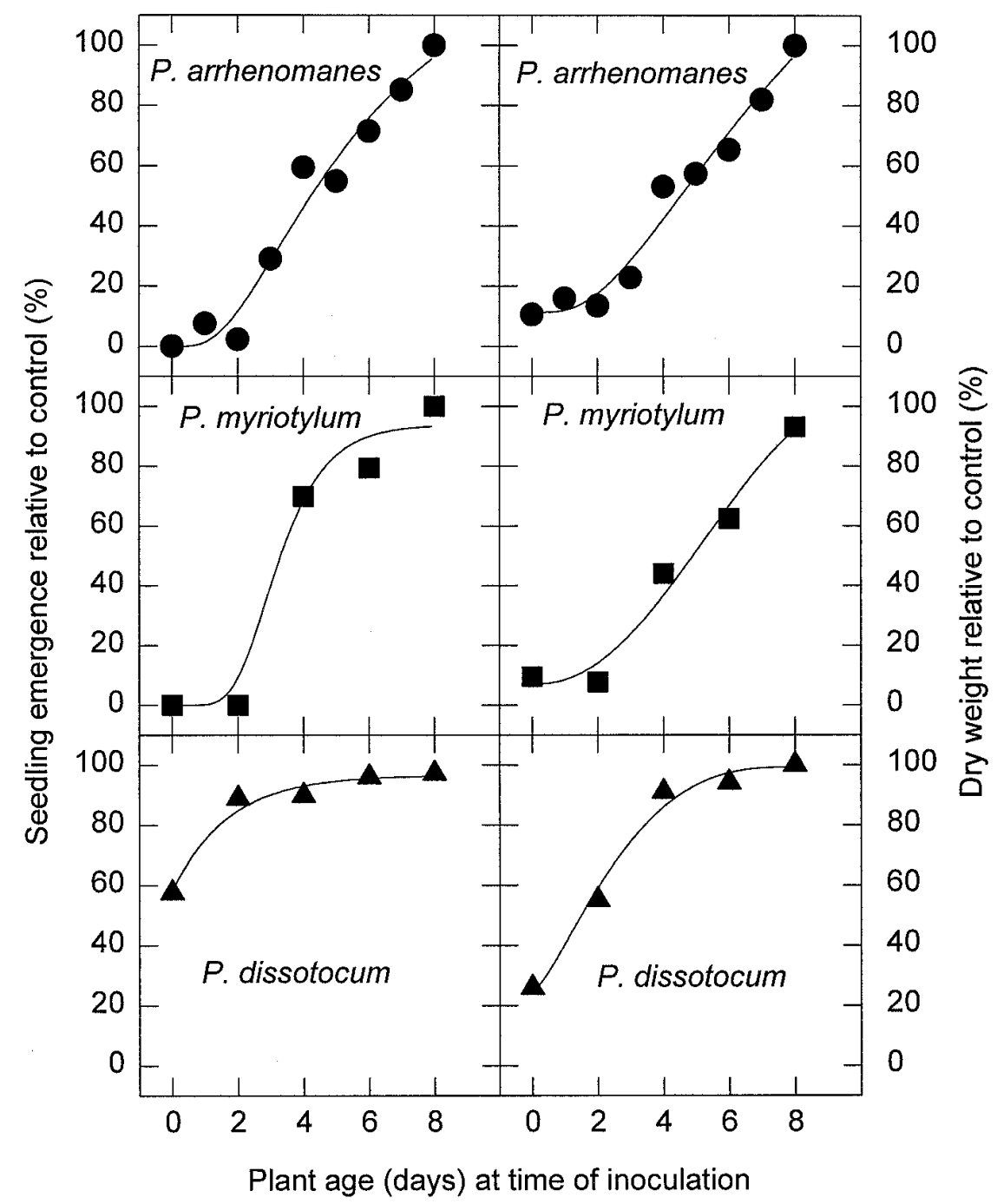

Fig. 5. Effect of rice seedling age at time of inoculation on susceptibility to Pythium spp. as determined by seedling emergence and dry weight relative to noninoculated controls. Emergence and dry weight were recorded at 10 days after the indicated time of inoculation. Lines were added for illustrative purposes. 
merged. It is at this time that growers would employ the cultural practice of draining their fields to promote rooting and shoot growth. Delayed root development is important because, unless seedlings are anchored to the soil surface, they are prone to being swept across the soil surface by wind-driven water currents. The result of seedling drift, even if the seedlings eventually emerge, is uneven stand establishment.

Krishna (13) reported that zoospores of Pythium spp. were selectively attracted toward germinating rice embryos and then attacked the primary radicle (13). However, Achlya spp. were shown to preferentially infect seed coats and endosperms $(13,27)$. Also, Webster et al. (27) suggested that the failure of seeds to germinate and the failure of seedlings to emerge through flood water may be caused by a weakening of the seedling through utilization of the energy reserve (endosperm) by A. klebsiana rather than by direct damage to the germinating embryo. Our results suggest that this is not the case with Pythium spp. Similar to our findings, Hering et al. (11) reported that there was a higher incidence of infection of embryos of wheat (Triticum aestivum) seeds by $P$. irregulare and $P$. ultimum var. sporangiferum compared with that of the endosperm. Furthermore, Cook et al. $(6,7)$ concluded that the variable stunting of seedlings and especially the abnormally short and twisted first true leaves of wheat seedlings grown in Pythium-infested soil, apparently were the result of early embryo infections. Such symptoms also were observed in rice in the current studies. In addition, wheat seeds pregerminated for only 2 days on moist filter paper and then transplanted to soil infested with Pythium showed none of these symptoms, and the seedlings were indistinguishable from those grown in Pythium-free soil (11). These results are remarkably similar to ours, in that the Pythium spp. used in this study did not cause tissue damage; rather, they retarded shoot growth and caused morphological abnormalities. According to Arndt (2), 6-day-old cotton plants were more susceptible than were 12-day-old plants to $P$. ultimum, which caused root necrosis and stunting at 24 and $27^{\circ} \mathrm{C}$. Red clover (Trifolium pratense) and Ladino white clover (Trifolium repens) developed complete resistance against $P$. debaryanum, $P$. ultimum, and $P$. irregulare within 2 days of germination (10). Also, similar to our findings, seedlings became resistant more quickly to the less virulent strains than to those that were more virulent (10).

Our demonstration that, in the presence of Pythium spp., emergence was reduced with greater water depth suggests that seedlings become resistant sooner in shallower water. This resistance may be related to the physiological state of submerged seedlings,

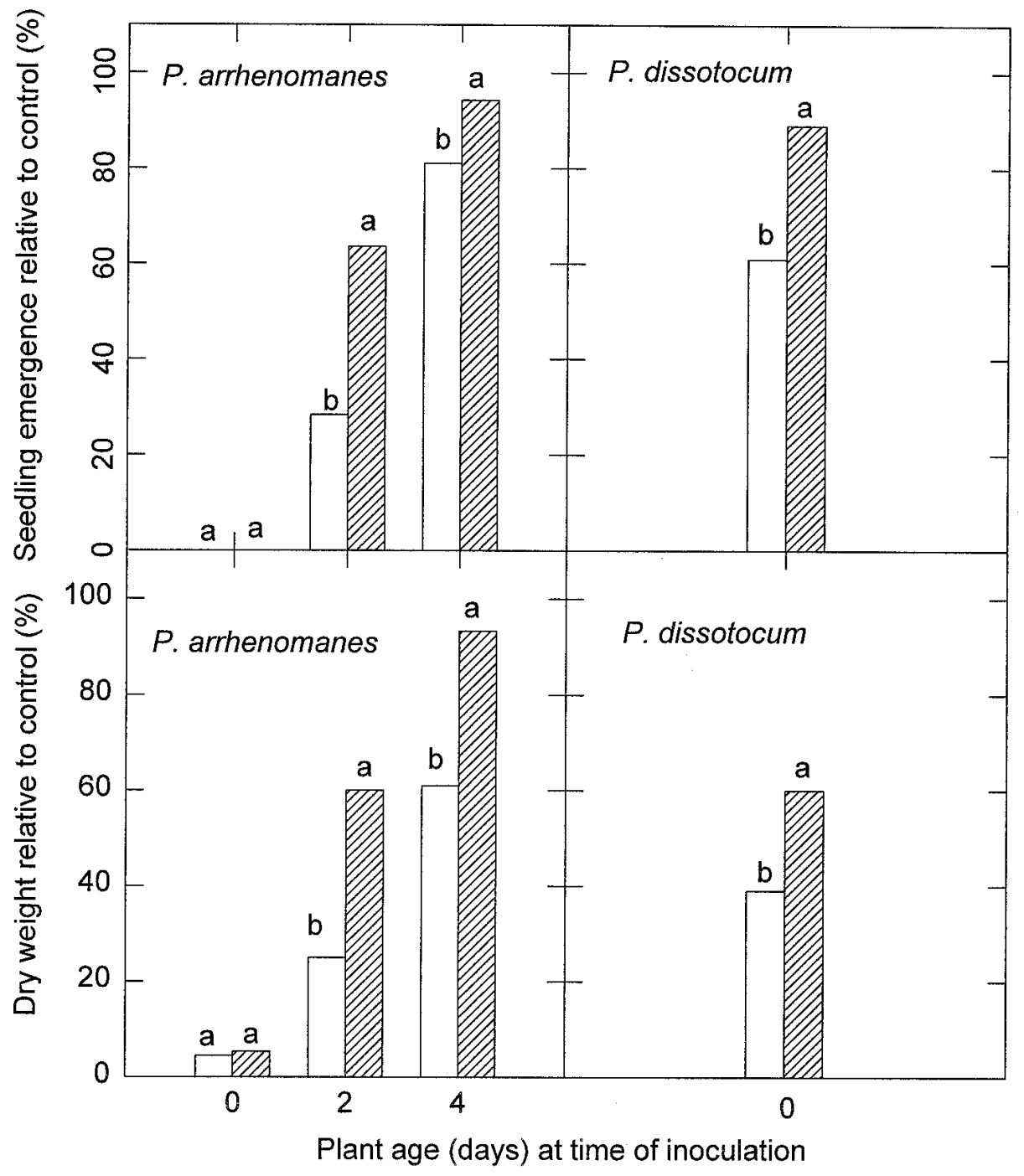

High water level $(4.5 \mathrm{~cm})$

WIII Low water level $(1.5 \mathrm{~cm})$

Fig. 6. Effects of water depth and rice seedling age on susceptibility to Pythium spp. as determined by seedling emergence and dry weight relative to noninoculated controls. Bars topped with the same letters within a day are not significantly different ( $t$ test, $P=0.05$ ). 
in that shoots of such seedlings remained yellow to pale green until the tips emerged from the water, at which time the entire shoot became dark green (S.-C. Chun and R. W. Schneider, unpublished data). Also, our findings (data not shown) confirm those of Yamauchi and Chuong (29), who showed that, in the absence of pathogens, rice seedling establishment was not affected by water level when seeds were sown on the soil surface, but they also reported that seedling establishment was reduced by raising the water level when seeds were sown below the soil surface. Our results corroborate the agronomic practice of maintaining a very shallow flood as a means of cultural control of seedling disease. While this tactic is employed in commercial practice, its effectiveness is limited because fields must be leveled precisely and uniform water depth cannot be maintained on large expanses because fields must be sloped to promote drainage. Thus, after planting, if conditions are favorable for disease development, growers drain their fields for a few days to promote soil penetration by seedling roots. In addition, we showed that a significant level of disease control could be achieved by the recently abandoned commercial practice of planting pregerminated seeds.

Our findings suggest that seedling disease in water-seeded rice should be amenable to biological control. Seedlings need to be protected for a very short period of time, as little as 2 or 3 days after planting under our test conditions, before they become resistant. In addition, the infection court is confined to a specific plant organ, the developing embryo, as opposed to the endosperm, the entire root system, or root tips. Thus, introduced organisms need not establish high populations on entire seeds or multiple plant organs for indefinite periods of time. It is these requirements that have frustrated investigators in their attempts to achieve biological control of such pathogens as Gaeumannomyces graminis var. tritici on wheat, because this pathogen infects older roots throughout the life of the plant (28). Finally, one of the most limiting factors in the successful utilization of biological control agents, the continuous availability of free moisture $(17,19)$, is not a constraint in water-seeded rice.

\section{ACKNOWLEDGMENTS}

This work is a portion of S.-C. Chun's Ph.D. dissertation and was supported, in part, by USDA National Research Initiative grant 94-37312-0626. Approved for publication by the Director of the Louisiana State Agricultural Experiment Station as manuscript 97-38-0460.

\section{LITERATURE CITED}

1. Anonymous. 1987. Rice Production Handbook. La. State Univ. Agric. Cent. Pub. No. 2321

2. Arndt, C. H. 1943. Pythium ultimum and the damping-off of cotton seedlings. Phytopathology 33:607-611.

3. Chun, S.-C., and Schneider, R. W. 1994. Sites of infection in rice seeds and seedlings by Pythium spp. (Abstr.) Phytopathology 84:1101.

4. Chun, S.-C., and Schneider, R. W. 1995. Seedling disease of water-seeded rice. Effect of plant age on susceptibility and minimum exposure time for infection by Pythium species. (Abstr.) Phytopathology 85:1124.

5. Chun, S.-C., Schneider, R. W., and Cohn, M. A. 1997. Sodium hypochlorite: Effect of solution $\mathrm{pH}$ on rice seed disinfestation and its direct effect on seedling growth. Plant Dis. 81:821-824.

6. Cook, R. J., and Haglund, W. A. 1982. Pythium root rot: A barrier to yield of Pacific Northwest wheat. Wash. State Coll. Agric. Res. Bull. XB0913.

7. Cook, R. J., and Hering, T. F. 1986. Infection of wheat embryos by Pythium and seedling response as influenced by age of the seed. (Abstr.) Phytopathology 76:1061.

8. Grist, D. H. 1975. Rice. Longman Group Ltd., London

9. Groth, D. E., Rush, M. C., and Hollier, C. A. 1991. Rice diseases and disorders in Louisiana. La. Agric. Exp. Stn. Bull. No. 828.

10. Halpin, J. E., and Hanson, E. W. 1958. Effect of age of seedlings of alfalfa, red clover, Ladino white clover, and sweet clover on susceptibility to Pythium. Phytopathology 48:481-485.

11. Hering, T. F., Cook, R. J., and Tang, W.-H. 1987. Infection of wheat embryos by Pythium species during seed germination and the influence of seed age and soil matric potential. Phytopathology 77:1104-1108.

12. Itos, S., and Nagai, M. 1931. On the rot disease of the seeds and seedlings of rice plants caused by aquatic fungi. J. Fac. Agric. Hokkaido Imp. Univ. 32:45-69.

13. Krishna, P. G. 1983. Etiology and control of the rice water-mold disease complex in Louisiana. M.S. thesis. Louisiana State University, Baton Rouge.

14. Lamey, H. A. 1965. A technique for laboratory evaluation of seed treatments to control rice seed rot. Plant Dis. Rep. 49:736-738.

15. Mircetich, S. M. 1971. The role of Pythium in feeder roots of diseased and symptomless peach trees and in orchard soils in peach tree decline. Phytopathology 61:357-360.

16. Ou, S. H. 1985. Rice Diseases. Commonwealth Mycological Institute, Kew, England.

17. Parke, J. L. 1991. Biological control of damping-off diseases with seed treatments. Pages 33-42 in: The Rhizosphere and Plant Growth. D. L. Keister and P. B. Cregan, eds. Kluwer Academic Publishers, Boston, MA.

18. Pillay, M., Schneider, R. W., and Rush, M. C. 1986. Association of Pythium species with seedling diseases and feeder root decline in rice. (Abstr.) Phytopathology 76:1094.

19. Powell, K. A. 1992. Biocontrol product fermentation, formulation and marketing. Pages 381-387 in: Biological Control of Plant Diseases. Progress and Challenges for the Future. E. C. Tjamos, G. C., Papavizas, and R. J. Cook, eds. Plenum Press, New York.

20. Rush, M. C. 1992. Seedling diseases. Pages 12-13 in: Compendium of Rice Diseases. R. K. Webster and P. S. Gunnell, eds. The American Phytopathological Society, St. Paul, MN.

21. Sawada, K. 1912. Studies on the rot disease of rice seedlings in Formosa. (In Japanese) Spec. Bull. Formosan Agric. Exp. Stn. 3:1-84.

22. Shahjahan, A. K. M., Hossain, M. A., and Rhaman, M. 1978. Occurrence of water mold disease of rice seed and seedlings in Bangladesh. Int. Rice Res. Newsl. 3(3):9.

23. Srinivasan, S., Chinnuswamy, P., and Venkataraman, R. 1976. Studies on the root rot of rice seedlings caused by Pythium sp. Madras Agric. J. 63:406-407.

24. Steel, R. G. D., and Torrie, J. H. 1980. Principles and Procedures of Statistics. McGraw-Hill, New York.

25. Sung, J. M., Jin, K. S., Lee, S. C., and Park, J. S. 1983. Identification and pathogenicity of Pythium spp. associated with seedling damping-off of rice. (In Korean) Korean J. Mycol. 11:27-32.

26. Thompson, R. A., Schneider, R. W., and Quisenberry, S. S. 1990. Timetemperature relationships in the development of seedling disease in water-seeded rice. (Abstr.) Phytopathology 80:1039.

27. Webster, R. K., Hall, D. H., Heeres, J., Wick, C. M., and Brandon, D. M. 1970. Achlya klebsiana and Pythium species as primary causes of seed rot and seedling disease of rice in California. Phytopathology 60:964-968.

28. Weller, D. M. 1988. Biological control of soilborne plant pathogens in the rhizosphere with bacteria. Annu. Rev. Phytopathol. 26:379-407.

29. Yamauchi, M., and Choung, P. V. 1995. Rice seedling establishment as affected by cultivar, seed coating with calcium peroxide, sowing depth, and water level. Field Crop Res. 41:123-134. 